\title{
Studies of Renal Injury
}

\section{Activation of the Glucose Transporter 1 (GLUT1) Gene and Glycolysis in LLC-PK1 Cells Under $\mathrm{Ca}^{2+}$ Stress}

\author{
Jesus H. Dominguez,, \\ and James McAteer \\ Departments of $*$ Medicine, ${ }^{\ddagger}$ Physiology and Biophysics, ${ }^{\S}$ Pathology and Laboratory Medicine, and $\|$ Anatomy, Indiana University Medical \\ Center and Veterans Administration Medical Center, Indianapolis, Indiana 46202
}

\begin{abstract}
Injury to the renal proximal tubule is common and may be followed by either recovery or cell death. The survival of injured cells is supported by a transient change in cellular metabolism that maintains life even when oxygen tension is reduced. This adaptive process involves the activation of the gene encoding the glucose transporter GLUT1, which is essential to maintain the high rates of glucose influx demanded by glycolysis. We hypothesized that after cell injury increases of cell $\mathrm{Ca}^{2+}\left(\mathrm{Ca}^{2+}{ }_{\mathrm{i}}\right)$ initiate the flow of information that culminates with the upregulation of the stress response gene GLUT1. We found that elevations of $\mathrm{Ca}^{2+}{ }_{\mathrm{i}}$ caused by the calcium ionophore A23187 activated the expression of the GLUT1 gene in LLC-PK1 cells. The stimulatory effect of $\mathrm{Ca}^{2+}{ }_{i}$ on GLUT1 gene expression was, at least in part, transcriptional and resulted in higher levels of GLUT1 mRNA, cognate protein, cellular hexose transport activity, glucose consumption, and lactate production. This response was vital to the renal cells, as its interruption severely increased $\mathrm{Ca}^{2+}$-induced cytotoxicity and cell mortality. We propose that increases of $\mathrm{Ca}^{2+}{ }_{\mathrm{i}}$ initiate stress responses, represented in part by activation of the GLUT1 gene, and that disruption to the flow of information originating from $\mathrm{Ca}^{2+}$ induced stress, or to the coordinated expression of the stress response, prevents cell recovery after injury and may be an important cause of permanent renal cell injury and cell death. (J. Clin. Invest. 1996. 98:395-404.) Key words: acute renal failure - glucose transport $\cdot$ renal tubule - cytosolic calcium
\end{abstract}

\section{Introduction}

Injury to renal proximal tubules is common and may result in cell recovery or cell death. The recovery process is promoted by a temporary change in cellular metabolism that allows tubular cells to survive even when oxygen tension is reduced (1, 2). This "metabolism of cell injury" involves the upregulation of stress genes that promote cell viability and enhance cell survival (3-15).

The increase of cell calcium in injured cells $(16,17)$ while cytotoxic in some cases $(16,17)$ appears to be the activating sig-

Address correspondence to Jesus H. Dominguez, M.D., Nephrology Section, N111, Veterans Administration Medical Center, 1481 W. 10th St., Indianapolis, IN 46202. Phone: 317-635-7401 ext. 2184; FAX: 317-267-8798.

Received for publication 30 September 1995 and accepted in revised form 12 April 1996.

The Journal of Clinical Investigation

Volume 98, Number 2, July 1996, 395-404 nal for the expression of genes involved in the stress response to hypoxia $(11,18)$ and to genotoxic agents such as $\mathrm{H}_{2} \mathrm{O}_{2}$, etoposide, and methyl methanesulfonate (5-7). Cells have evolved a stereotypical response to calcium stress that comprises the activation of early response and stress response genes. In epithelial and other cells increases of calcium activate the expression of the protooncogenes c-myc, c-fos, and c-jun (14). The products of these early response genes act as transcription regulators that may participate in cell growth, although their specific roles in calcium stress are undetermined (18). The functions of other $\mathrm{Ca}^{2+}$ stress response gene products are better defined. For example, the hsp70 protein offers cytoprotection to cells exposed to heat or calcium stress $(7,8$, 18). The product of calcium-inducible gadd 153 takes part in DNA arrest (19), and the product of GRP78 retains misfolded proteins in the endoplasmic reticulum (13).

When oxidative phosphorylation is not possible due to cell injury or hypoxia, glycolysis becomes the main metabolic pathway for substrate utilization $(1,2,4)$. Thus, renal proximal tubules increase glycolytic activity as oxidative metabolism is decreased when subjected to hypoxic stress $(1,2)$. This change in function, known as the Pasteur effect $(3,4)$, assures tubular production of ATP through anaerobic glycolysis and therefore preserves tubular viability and even transport function $(1,2)$. However, the production by glycolytic pathways of 2 moles of ATP per mole of glucose consumed is much less efficient than the yield from oxidative phosphorylation (1-4). Consequently, the first requirement for injured tubules to keep up with metabolic demands is to drastically enhance glycolytic flux, which begins by increasing glucose uptake through high affinity glucose transporters $(1,2)$. This action is conducted in part by upregulating the expression of low $K_{\mathrm{m}}$ glucose transporter 1 $\left(\right.$ GLUT1 $^{1}(20,21)$ in injured cells $(3,4,12,15,22)$. Failure to translate the upregulation of stress response genes into functional proteins may aggravate the injury (23).

In this work, we tested the primary hypothesis that increases of cell calcium, common in injured cells (24), activate the expression of the gene encoding the ubiquitous glucose transporter GLUT1 in renal cells. We also tested the secondary hypothesis that disruption of this stress response resulted in greater cytotoxicity and cell mortality. We found that calcium stress provoked with the ionophore A23187 activated calcium-dependent transcription of the GLUT1 gene in LLCPK1 cells. This response resulted in greater levels of GLUT1 mRNA, cognate protein, higher glucose influx, and glycolytic rates within hours. Moreover, this acute response was of critical importance for cell survival, as its interruption resulted in greater cytotoxicity and mortality.

1. Abbreviations used in this paper: $\mathrm{Ca}^{2+}$, cytosolic calcium; 2-DG, 2-deoxyglucose; GLUT1, glucose transporter 1 ; ${ }^{3} \mathrm{H}-\mathrm{DG},{ }^{3} \mathrm{H}$-deoxyD-glucose; LDH, lactic dehydrogenase. 


\section{Methods}

Cells and culture conditions. The porcine proximal tubule-like cell line LLC-PK1 (ATCC CRL 1392; reference 25) was obtained from the American Type Culture Collection (Rockville, MD). LLC-PK1 cells exhibit marker and functional attributes of proximal tubule cells (26). They express the $\mathrm{Na}^{+}$-glucose cotransporter 1 in the lumen, whereas in their basolateral surface the only facilitative glucose transporter expressed is GLUT1 (21, 26, and unpublished data from J. Dominguez). The cells were cultured on $100 \mathrm{~mm}\left(78.5 \mathrm{~cm}^{2}\right)$ culturegrade plastic dishes in nutrient $\alpha$-modified Eagle medium ( $\alpha$ MEM) supplemented with $2 \mathrm{mM}$ glutamine, $10 \%$ FCS, and $5.5 \mathrm{mM}$ glucose unless indicated otherwise. The glucose concentration in the medium was monitored with a glucose electrode, and the medium was replenished every day.

The experimental protocols were conducted in confluent cells, unless stated otherwise. LLC-PK1 cells were placed in media containing either vehicle (DMSO $0.1 \%$ ) or $10 \mu \mathrm{M}$ A23187 for $4 \mathrm{~h}$, washed three times with PBS, and allowed to recover for 20 more hours. In some experiments the cells were pretreated with the extracellular calcium chelator ethylene bis (oxyethylenenitrilo)-tetraacetic acid (EGTA), $2.5 \mathrm{mM}$, or the intracellular calcium chelator [1,2-bis-(o-aminophenoxy)-ethene-N,N, $\mathrm{N}^{\prime}, \mathrm{N}^{\prime}$-tetraacetic acid tetra-(acetoxymethyl)-ester] (BAPTA-AM), $20 \mu \mathrm{M}$ (27). At the conclusion of the experimental manipulations the cells were washed with PBS, scraped off the plastic, and processed. One-third of the cells was homogenized on ice with a glass/Teflon ${ }^{\circledR}$ homogenizer in TES-PI buffer containing (in $\mathrm{mM}$ ): Tris $\mathrm{HCl}, 20$; sucrose, 255; and EDTA (ethylenediamine-tetraacetate), 1 , plus leupeptin, $5 \mu \mathrm{g} / \mathrm{ml}$; pepstatin, $5 \mu \mathrm{g} / \mathrm{ml}$; and aprotinin, 5 $\mu \mathrm{g} / \mathrm{ml}, \mathrm{pH}$ 7.4. Another third was saved for mRNA measurements, and the remaining third for protein (28) and DNA (29) analyses.

Measurements of cytosolic free calcium. Cytosolic calcium $\left(\mathrm{Ca}^{2+}{ }_{\mathrm{i}}\right)$ was measured in LLC-PK1 cells by a modification of the fura2 method as reported by our laboratory (30). Cells were loaded with $12.5 \mu \mathrm{M}$ fura2-AM and $0.0025 \%$ pluronic acid in MEM for $40 \mathrm{~min}$ at $37^{\circ} \mathrm{C}$, washed in PBS, and resuspended for fluorescence determinations in assay buffer (in $\mathrm{mM}$ ): $\mathrm{NaCl}, 145 ; \mathrm{KCl}, 5 ; \mathrm{MgCl}_{2}, 1 ; \mathrm{CaCl}_{2}, 1.5$; glucose, 5; ( $\mathrm{N}$-[2-hydroxyethyl]piperizine- $\mathrm{N}^{\prime}$-[2-ethylsulfonic acid]) (Hepes), 7; $\mathrm{KH}_{2} \mathrm{PO}_{4}, 0.1$; and $\mathrm{K}_{2} \mathrm{HPO}_{4}, 0.5 ; \mathrm{pH}$ 7.4. $\mathrm{Ca}^{2+}{ }_{\mathrm{i}}$ was monitored before and after addition of $10 \mu \mathrm{M}$ A23187-4 bromo in the sample compartment of a DeltaScan double beam spectrofluorimeter. The $\mathrm{Ca}^{2+}{ }_{\mathrm{i}}$ values were calculated from the fluorescence elicited by the ratio of dual excitation wavelengths $(340 / 380 \mathrm{nM})$ detected at a single emission wavelength of $540 \mathrm{nM}$.

Measurements of 2-deoxyglucose (2-DG) uptake. LLC-PK1 cells were grown on $35-\mathrm{mm}$ diameter dishes $\left(9.6 \mathrm{~cm}^{2}\right)$. At the indicated times, the medium was aspirated from the cells and they were washed once with $1 \mathrm{ml}$ of Krebs-Ringer-Hepes buffer (KRH in $\mathrm{mM}$ ): 121 $\mathrm{NaCl}, 4.9 \mathrm{KCl}, 1.2 \mathrm{MgSO}_{4}, 0.33 \mathrm{CaCl}_{2}, 12 \mathrm{Hepes}, \mathrm{pH} 7.4$, at $37^{\circ} \mathrm{C} .1 \mathrm{ml}$ of uptake solution (KRH buffer with $0.1 \mu \mathrm{M}$ 2-DG and $1 \mu \mathrm{Ci} / \mathrm{ml}{ }^{3} \mathrm{H}$ 2-DG) was added to each dish for $3 \mathrm{~min}$ (uptake was linear for $5 \mathrm{~min}$, data not shown) at $37^{\circ} \mathrm{C}$. The cells were subsequently washed three times with $1 \mathrm{ml}$ of ice-cold KRH buffer and solubilized with $1 \mathrm{ml}$ of $1 \mathrm{~N} \mathrm{NaOH}$. $500 \mu \mathrm{l}$ of this solution was used for $\beta$ radioactivity scintillation counting and the remaining $500 \mu \mathrm{l}$ was neutralized with $\mathrm{HCl}$ and used for protein determination. $5 \mu \mathrm{M}$ cytochalasin B was included in half of the dishes to determine nonspecific diffusion and that value was subtracted from total ${ }^{3} \mathrm{H}-2-\mathrm{DG}$ cellular uptake to estimate transporter-specific hexose flux (31). The uptake data were expressed as moles of 2-deoxyglucose, determined from the specific activity of ${ }^{3} \mathrm{H}-2-\mathrm{DG}$ in the uptake solution, without or with cytochalasin $\mathrm{B}$, and ${ }^{3} \mathrm{H}$ incorporated in cells.

Measurements of glucose and lactate in culture medium. Six groups of confluent LLC-PK1 cells (35-mm diameter dishes) were exposed to either $0.1 \%$ DMSO (vehicle) or $10 \mu \mathrm{M}$ A23187 for 4-24 h periods. The cells were cultured in $\alpha$ MEM with $2 \mathrm{mM}$ glucose, $2 \mathrm{mM}$ glutamine, and $10 \mu \mathrm{M}$ phlorizin (added to reduce glucose influx through the $\mathrm{Na}^{+} /$glucose cotransporter; 26). In some experiments, $0.1 \mathrm{mM}$ phlore- tin was also included in the culture media to inhibit facilitative glucose flux through GLUT1 (20). At the end of each time period the culture medium was aspirated, centrifuged $\left(16,000 \mathrm{~g}, 5 \mathrm{~min}, 4^{\circ} \mathrm{C}\right)$ and analyzed immediately for glucose and lactate concentrations with a YSI 2300 STAT glucose/lactate analyzer (Yellow Springs Instrument Co., Yellow Springs, OH).

Measurements of cellular and medium lactic dehydrogenase ( $L D H)$ levels. LDH levels were measured by the method of Korzeniewski and Callewaert (32) in LLC-PK1 cells cultured in $\alpha$ MEM with $5 \mathrm{mM}$ glucose and $10 \mu \mathrm{M}$ phlorizin. Total LDH produced in each culture dish was measured. Total LDH was the sum of intracellular LDH measured in LLC-PK1 cells washed with and homogenized in PBS, plus LDH released into the media. The percent LDH released in the medium was calculated as: [(medium LDH/total LDH) $\times 100]$.

Western blot analysis. LLC-PK1 cells were homogenized on ice with a glass/Teflon ${ }^{\circledR}$ homogenizer in TES-PI buffer. The cell homogenates were solubilized in Laemmli sample buffer and analyzed by SDS-PAGE on 1.5 -mm slab gels containing $8 \%$ polyacrylamide (33). The proteins were electrophoretically transferred to nitrocellulose (34) and reacted with specific polyclonal antibodies raised in rabbits against a synthetic peptide representing the last 12 amino acids at the $\mathrm{COOH}^{-}$end of the rat GLUT1 protein (35) (East Acres Biologicals, Southbridge, MA). Polyclonal antibody to the $\alpha_{1}$ subunit of $\mathrm{Na}^{+} / \mathrm{K}^{+}$ ATPase was raised in rabbits immunized with a peptide fragment of the subunit corresponding to amino acid residues 338-518 (Upstate Biotechnology Inc., Lake Placid, NY). The cross-reacting proteins were identified with ${ }^{125}$ I-protein A followed by autoradiography and quantitated on the membranes by $\beta$ radioactivity scanning (AMBIS).

Northern and dot blot analysis. LLC-PK1 cells were disrupted in $10 \mathrm{ml}$ of a solution containing $4 \mathrm{M}$ guanidinium isothiocynate, $25 \mathrm{mM}$ $\mathrm{Na}^{+}$citrate, $\mathrm{pH} 7.0,0.5 \%$ sarkosyl, and $0.7 \% \beta$-mercaptoethanol. Total RNA was recovered (by adding $0.5 \mathrm{ml}$ of $2 \mathrm{M}$ potassium acetate, $\mathrm{pH} 5.5$, and $0.8 \mathrm{ml}$ of $1 \mathrm{M}$ acetic acid, plus $7.5 \mathrm{ml}$ of ethanol $-20^{\circ} \mathrm{C}$ overnight) dissolved in DEPC-treated $\mathrm{H}_{2} \mathrm{O}$, and quantity and purity assessed by spectrophotometry at $260 / 280 \mathrm{nM}$ wavelength (36). $20 \mu \mathrm{g}$ of RNA were denatured in formaldehyde and size-fractionated in $1 \%$ agarose gels where integrity and relative amounts of RNA were checked by ultraviolet shadowing. The RNA was transferred to "Nytran" nylon membranes by capillarity (Schleicher and Schuell Inc., Keene, NH). mRNA from LLC-PK1 cells was also measured on dot blots according to the manufacturer's instructions (Schleicher and Schuell Inc.). $20 \mu \mathrm{g}$ of RNA was dissolved in $100 \mu \mathrm{l}$ of DEPC water with $200 \mu \mathrm{l}$ of $6.15 \mathrm{M}$ formaldehyde plus $5 \times$ SSC $(1 \times$ SSC is 150 $\mathrm{mM} \mathrm{NaCl}$ and $15 \mathrm{mM} \mathrm{Na-citrate,} \mathrm{pH}$ 7.0), and then blotted using vacuum on Nytran nylon membranes (37), rinsed under vacuum with $5 \times$ $\mathrm{SSC}$, dried, and baked $\left(80^{\circ} \mathrm{C}, 2 \mathrm{~h}\right)$ under vacuum. The RNA on the membranes was hybridized (38) at high stringency $(50 \%$ formamide, $2 \times$ Denhardt's solution, $1 \%$ SDS, $5 \times$ SSC, and salmon sperm DNA, $100 \mu \mathrm{g} / \mathrm{ml}$, at $\left.42^{\circ} \mathrm{C}\right)$ to porcine $\operatorname{GLUT} 1 \mathrm{cDNA}(21,39)$ and then to rat $28 \mathrm{~S}$ rRNA (40), both labeled with ${ }^{32} \mathrm{P}-\mathrm{ATP}$ to a sp act of $0.5-1 \times 10^{9}$ $\mathrm{cpm} / \mu \mathrm{g}$ by the oligolabeling method (41). The membranes were washed in $0.2 \%$ SDS and $0.1 \times \mathrm{SSC}$ at $52^{\circ} \mathrm{C}$ and exposed to Kodak XAR-5 film at $-70^{\circ} \mathrm{C}$ with a Cronex (DuPont, Wilmington, DE) intensifying screen. Cross hybridizing mRNAs were depicted by autoradiography and then quantitated on the membranes by $\beta$ radioactivity scanning (AMBIS).

pUCAT and $p G P C A T_{333}$ constructs. We engineered pUCAT and pGPCAT $_{333}$ to measure the transcriptional activity of the GLUT1 gene in vivo. pUCAT was constructed from original pUC19 that served as template (42). A 1634 HindIII-BamHI fragment containing the chloramphenicol acetyltransferase (CAT) gene isolated from pSV2CAT (43). The $5^{\prime}$ overhang ends of this fragment were converted to blunt ends by filling in the ends with the Klenow enzyme in the presence of dNTP. This fragment was inserted into pUC19 at the SacI site which was converted to blunt ends with the single-stranded specific enzyme S1. pGPCAT 333 was engineered by subcloning the last $333 \mathrm{bp}$ of the rat GLUT1 promoter fragment located in the $5^{\prime}$ 


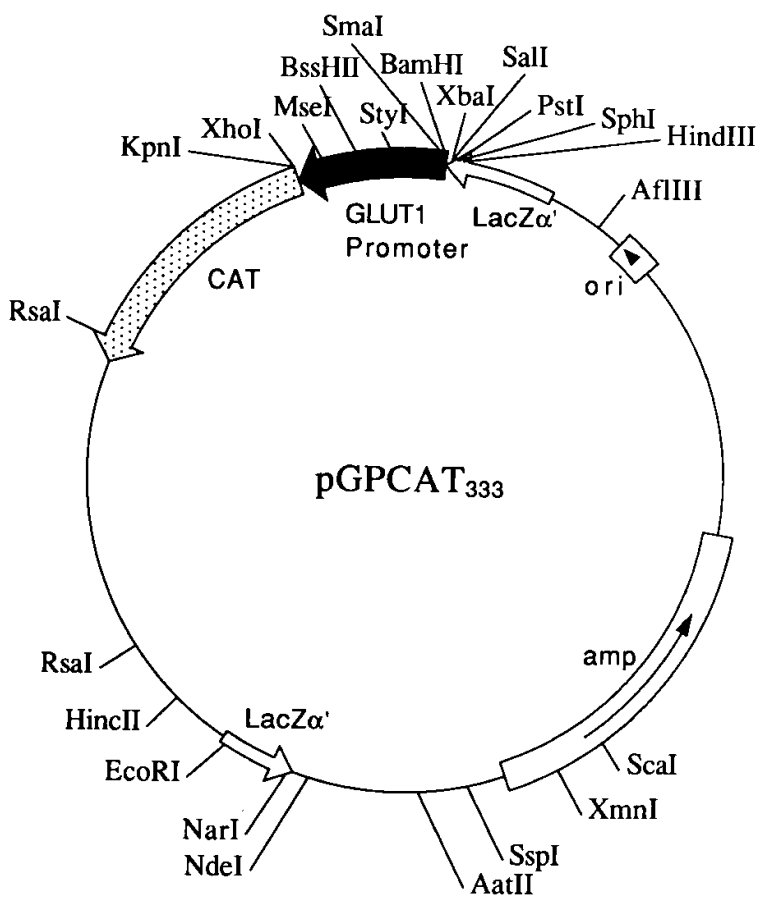

Figure 1. The construct pGPCAT $\mathrm{T}_{333}$. The CAT gene, including the polyadenylation sequence from the $\mathrm{SV}$ region, was subcloned into pUC19. The resulting construct was designated pUCAT. We then subcloned into pUCAT, in a $5^{\prime} \rightarrow 3^{\prime}$ direction, the last $333 \mathrm{bp}$ of the GLUT1 promoter fragment located in the $5^{\prime}$ flanking region of the GLUT1 gene. The 333-bp fragment contained the transcription initiation site and was located between restriction sites $5^{\prime}$ SmaI and $3^{\prime}$ XhoI of the GLUT1 promoter (44). This reporter construct was designated pGPCAT $\mathrm{T}_{333}$.

flanking region of the GLUT1 gene into pUCAT. The GLUT1 promoter fragment was contained within the restriction sites $5^{\prime} \mathrm{SmaI}$ and $3^{\prime}$ XhoI, which were used to cut and isolate the fragment from a $2.1-\mathrm{kb}$ promoter segment donated to us by Dr. Morris Birnbaum (Harvard University, Cambridge, MA) (44). The 333-bp GLUT1 promoter

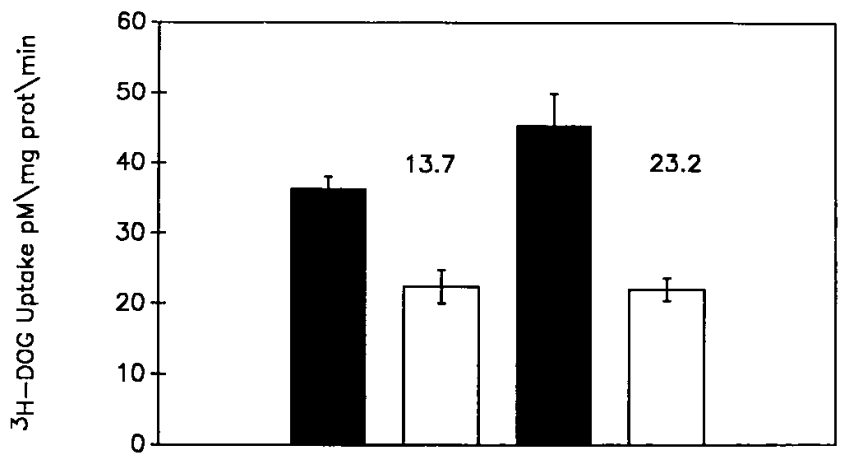

Figure 2. ${ }^{3} \mathrm{H}-\mathrm{DG}$ uptake in LLC-PK cells. The first two bars represent, from left to right, total ${ }^{3} \mathrm{H}-\mathrm{DG}$ uptake in control cells in the absence of cytochalasin (solid) and in the presence of $5 \mu \mathrm{M}$ cytochalasin (open). The second two bars represent total ${ }^{3} \mathrm{H}-\mathrm{DG}$ uptake in cells exposed to $10 \mu \mathrm{M}$ A23187 in the absence of cytochalasin (solid) and in the presence of $5 \mu \mathrm{M}$ cytochalasin (open). The data are means and $\mathrm{SE}$ for $n=6$. The numbers 13.7 and 23.2 are the mean values for cytochalasin-sensitive ${ }^{3} \mathrm{H}-\mathrm{DG}$ uptake in control and A23187 treated cells, respectively.
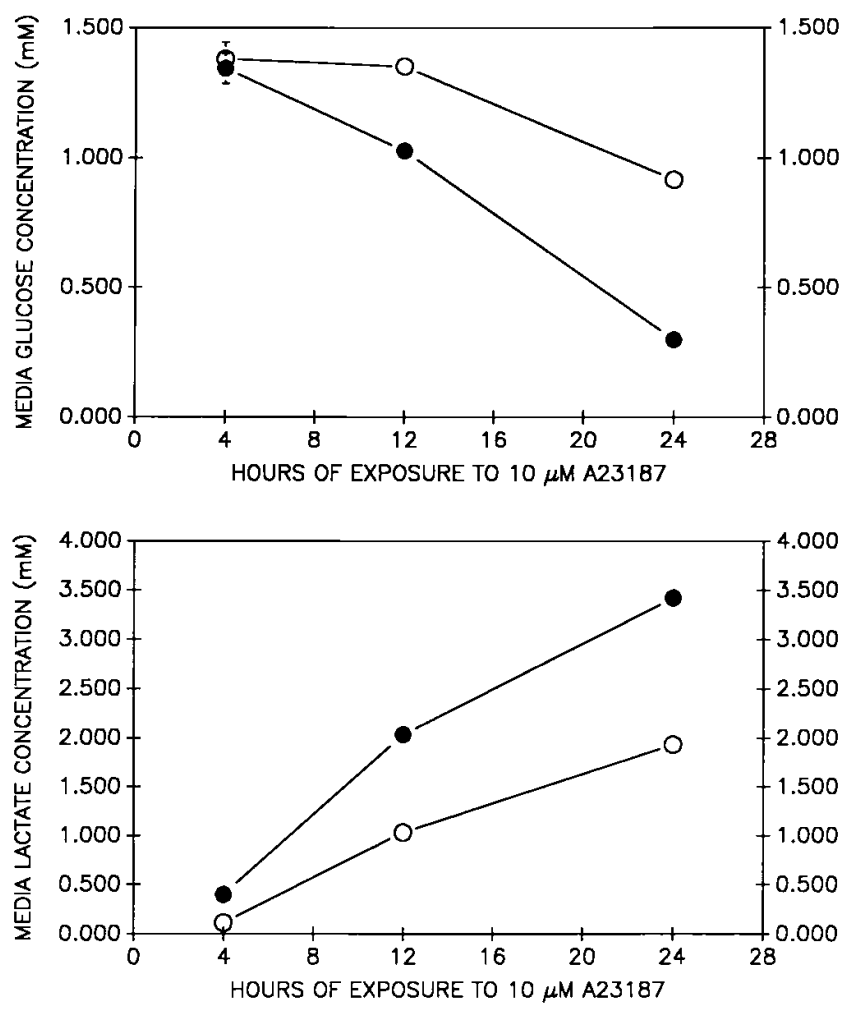

Figure 3. The levels of glucose (top) and lactate (bottom) in the media. LLC-PK1 cells were cultured in the presence of vehicle $(0.1 \%$ DMSO, open circles, $n=3$ ) or $10 \mu \mathrm{M}$ A23187 for 4,12 , or $24 \mathrm{~h}$ (closed circles, $n=3$ ). The culture medium was supplemented with $2 \mathrm{mM}$ glucose, $2 \mathrm{mM}$ glutamine and $10 \mu \mathrm{M}$ phlorizin was added to inhibit glucose flux through $\mathrm{Na}^{+}$/glucose cotransporters (26). The data show that A23187 increased glucose consumption and lactate production.

fragment was subcloned in a $5^{\prime} \rightarrow 3^{\prime}$ orientation immediately upstream from the CAT gene (Fig. 1). The proper orientation and base composition of pGPCAT $_{333}$ were verified by sequencing the 333-bp fragment plus both junctional ends of pUCAT with Sequenace v. 2.0 (United States Biochemical, Cleveland, $\mathrm{OH}$ ).

Measurements of GLUT1 gene transcription in vivo. LLC-PK1 cells, $30-50 \%$ confluent grown on $10-\mathrm{cm}$ diameter culture dishes, were cotransfected by the calcium phosphate precipitation method (45, protocol 9.1.1) with pGPCAT G $_{333}(5-15 \mu \mathrm{g})$ and pCH110 $(1.5 \mu \mathrm{g})$ containing the $\beta$-galactosidase gene driven by the simian virus 40 early promoter (SV promoter, 45,46 ). The transfected LLC-PK1 cells were grown for an additional $72 \mathrm{~h}$, and then exposed to the experimental maneuvers. The culture media were removed, and the cells washed three times with PBS. To measure the activity of the enzyme CAT in transfected cells, $1 \mathrm{ml}$ of cell lysis buffer (Promega Corp., Madison, WI) was added to the dishes, and after 15 min the cells were scraped off and centrifuged $(12,000 \mathrm{~g}, 5 \mathrm{~min})$. CAT activity was measured in 60-80 $\mu \mathrm{l}$ aliquots of centrifuged cell lysate with $50 \mu \mathrm{l}$ of $1 \mathrm{M}$ Tris, $\mathrm{pH} 8.0 ; 10 \mu \mathrm{l}$ of ${ }^{14} \mathrm{C}$-chloramphenicol, $0.1 \mu \mathrm{Ci}$; and $20 \mu \mathrm{l}$ of 20 $\mathrm{mM}$ acetyl CoA (45). The reaction was conducted for $2-4 \mathrm{~h}$ at $37^{\circ} \mathrm{C}$, and the products, ${ }^{14} \mathrm{C}$-chloramphenicol and its metabolites, were extracted with $900 \mu \mathrm{l}$ of ethyl acetate and vacuum dried. The sample was resuspended with $30 \mu \mathrm{l}$ of ethyl acetate, and $15 \mu \mathrm{l}$ were then spotted on a thin layer chromatography plate, resolved with chloroform:methanol (95:5) and quantitated by $\beta$ radioactivity scanning with an AMBIS $\beta$ scanner. $\beta$-galactosidase was measured in cell lysates $(200 \mu \mathrm{l})$ added to $500 \mu \mathrm{l}$ of a solution containing $60 / 40 \mathrm{mM}$, $\mathrm{Na}_{2} \mathrm{HPO}_{4} / \mathrm{NaH}_{2} \mathrm{PO}_{4} ; 10 \mathrm{mM}, \mathrm{KCl} ; 1 \mathrm{mM}, \mathrm{MgCl}_{2} ; 50 \mathrm{mM}$, 2-mercaptoethanol; and $100 \mu \mathrm{l}$ of $O$-nitrophenyl- $\beta$-D-galactopyranoside; $2 \mu \mathrm{g} / \mathrm{ml}$, 

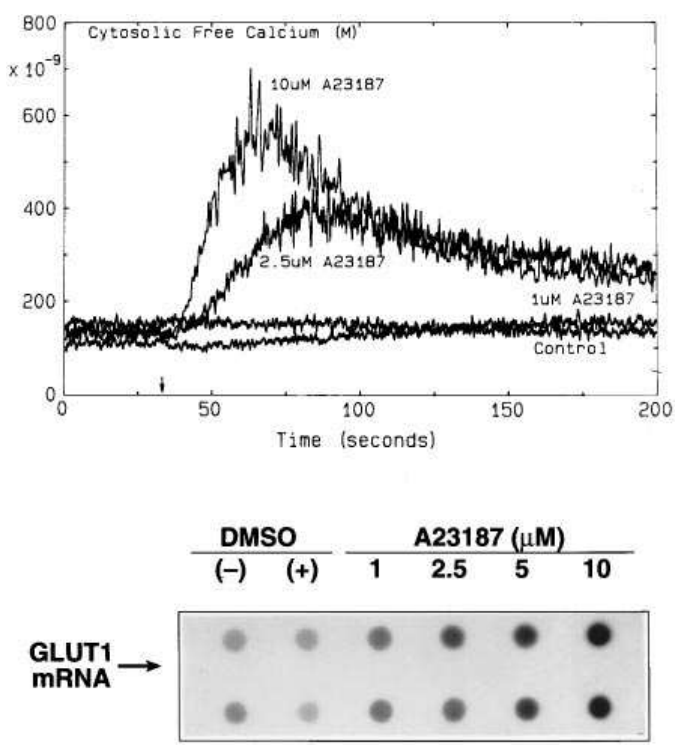

Figure 4. Cytosolic free $\mathrm{Ca}^{2+}\left(\mathrm{Ca}^{2+}{ }_{\mathrm{i}}\right.$, top $)$ and GLUT1 mRNA levels (bottom) in LLC-PK1 cells exposed to 0.1\% DMSO or 1-10 $\mu \mathrm{M}$ A23187. $\mathrm{Ca}^{2+}{ }_{i}$ was measured with fura2 and GLUT1 mRNA on dot blots. Whereas DMSO did not affect the levels of $\mathrm{Ca}^{2+}{ }_{\mathrm{i}}$ or GLUT1 mRNA, A23187 caused an incremental increase in both $\mathrm{Ca}^{2+}{ }_{\mathrm{i}}(n=2$ per point) and GLUT1 mRNA levels ( $n=3$ per point).

and incubated $\left(37^{\circ} \mathrm{C}, 20 \mathrm{~min}\right)$. The reaction was stopped with $500 \mu \mathrm{l}$ of $\mathrm{Na}_{2} \mathrm{CO}_{3}$, and the product calculated from the OD read at $420 \mathrm{nM}$. CAT activity is expressed as percent conversion of total ${ }^{14} \mathrm{C}$-chloramphenicol to the mono and diacetylated forms, normalized to $\beta$-galactosidase activity (45).
Figure 5. Measurements of cytosolic free calcium $\left(\mathrm{Ca}^{2+}{ }_{\mathrm{i}}\right)$ in LLCPK1 cells exposed to $10 \mu \mathrm{M}$ A23187 (arrow). The tracings represent three conditions: cells in control assay buffer, cells in assay medium chelated with $2 \mathrm{mM}$ EGTA, and cells chelated with $20 \mu \mathrm{M}$ BAPTA-AM and then suspended in assay medium. The addition of $10 \mu \mathrm{M}$ A23187 increased $\mathrm{Ca}^{2+}{ }_{\mathrm{i}}$ in all groups, but external and internal $\mathrm{Ca}^{2+}$ chelation blunted the rise of $\mathrm{Ca}^{2+}$. The tracings are representative of five to seven experiments.

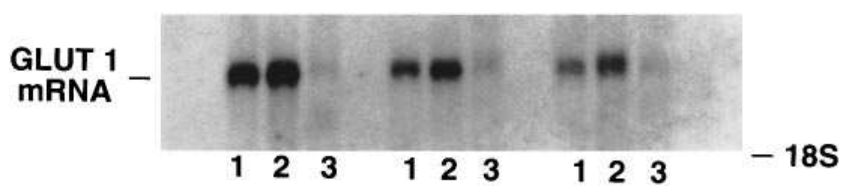

Figure 6. Northern blot analysis of mRNA encoding the GLUT1 gene in LLC-PK1 cells. Total RNA was extracted from three groups of cells: control (1), exposed to $10 \mu \mathrm{M}$ A23187 (2), or to EGTA $2 \mathrm{mM}$ followed by $10 \mu \mathrm{M}$ A23187 (3). $20 \mu \mathrm{g}$ of cell RNA were loaded on each lane, and high stringency hybridization was performed with ${ }^{32} \mathrm{P}$ dCTP-labeled cDNA encoding GLUT1. Exposure to A23187 for $4 \mathrm{~h}$ increased GLUT1 mRNA levels, whereas prior exposure to EGTA blunted the effect of A23187. Three separate experiments are represented.

Materials. BSA and ${ }^{14} \mathrm{C}$-chloramphenicol were from ICN Biomedicals, Irvine, CA. ${ }^{3} \mathrm{H}$-2-deoxyglucose, ${ }^{32} \mathrm{P}$-dCTP, and ${ }^{125} \mathrm{I}$-protein A were from Dupont-New England Nuclear, Boston, MA. Percoll, formamide, Denhardt's solution, SDS, guanidinium isothiocyanate, sodium citrate, $\mathrm{pH}$ 7.0, sarcosyl, leupeptin, pepstatin, aprotinin, and $\beta$-mercaptoethanol were from Sigma Chemical Co., St. Louis, MO. The nitrocellulose and nylon membranes were from Schleicher and Schuell Inc. Rabbit antibodies to rat GLUT1 and rat $\alpha_{1}$ subunit of $\mathrm{Na}^{+} / \mathrm{K}^{+}$ATPase were purchased from East-Acres Biologicals, Southbridge, MA and UBI, Lake Placid, NY, respectively. The $\beta$ scanner was from AMBIS, San Diego, CA, and the DeltaScan spectrofluorimeter was from Photon Technology International, Princeton, NJ.

Statistical analysis. The data are expressed as mean \pm SEM. Statistical differences between groups were calculated with Student's $t$ test for unpaired groups and ANOVA with Bonferonni's $t$ test.

\section{Results}

Activation of glucose transport and glycolysis. LLC-PK1 cells were exposed to control vehicle (0.1\% DMSO) or $10 \mu \mathrm{M}$ A23187 for $4 \mathrm{~h}$ in MEM, washed with PBS three times, and then cultured in fresh media for an additional $20 \mathrm{~h}$. The effect of

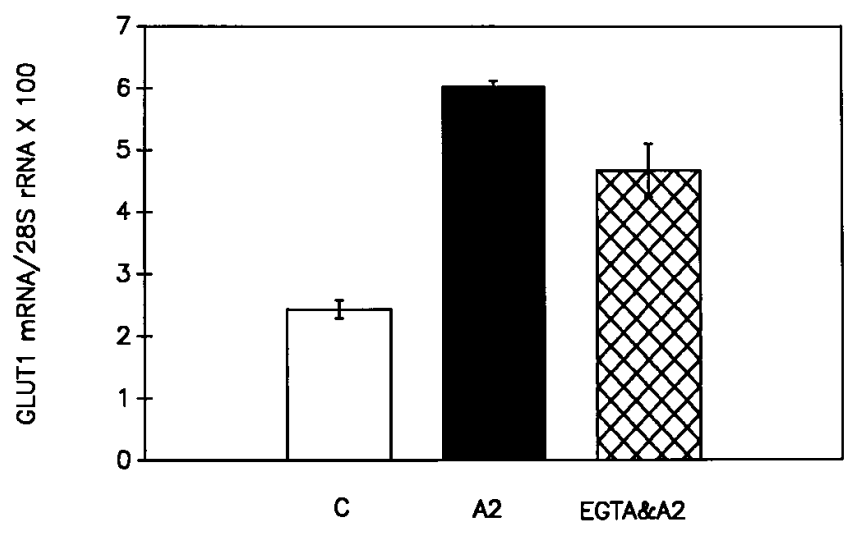

Figure 7. The fractional ratio GLUT1 mRNA/28S rRNA $\times 100$. Exposure to $10 \mu \mathrm{M}$ A23187 increased GLUT1 mRNA/28S rRNA $\times 100$, and EGTA reduced the effect. A23187 alone or with EGTA had a minimal effect on LLC-PK1 28S rRNA. The data represent three independent experiments. 


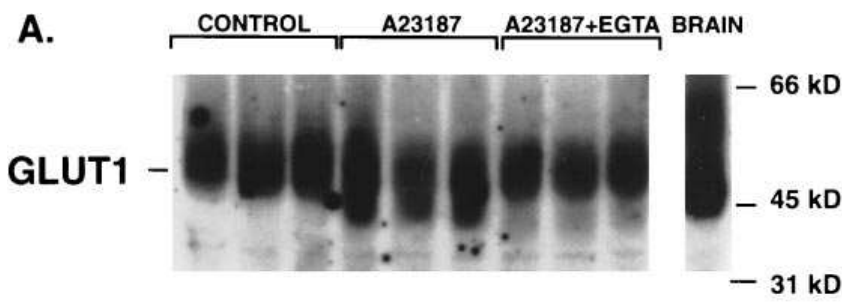

B.

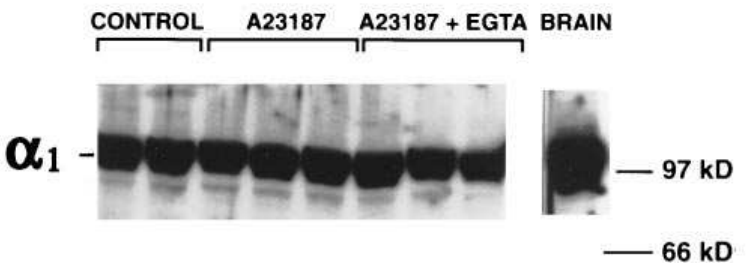

Figure 8. Western blot analysis of GLUT1 and $\alpha_{1}$ subunit of $\mathrm{Na}^{+} / \mathrm{K}^{+}$ ATPase $\left(\alpha_{1}\right)$ detected in homogenates of LLC-PK1 cells. Cell protein from three separate groups of cells was included: control, exposed to $10 \mu \mathrm{M}$ A23187, or to EGTA $2 \mathrm{mM}$ followed by $10 \mu \mathrm{M}$ A23187. GLUT1 protein levels increased after exposure to $10 \mu \mathrm{M}$ A23187 alone. The prior addition of $2 \mathrm{mM}$ EGTA attenuated the effect of the ionophore. In contrast, levels of the $\alpha_{1}$ subunit of $\mathrm{Na}^{+} / \mathrm{K}^{+}$ATPase were not changed by the experimental conditions. The transport proteins were detected after size-fractionation of protein $(100 \mu \mathrm{g})$ by immunoblotting with GLUT1 or $\alpha_{1}$ subunit of $\mathrm{Na}^{+} / \mathrm{K}^{+}$ATPase antibodies. Numbers indicate apparent molecular weight in $\mathrm{kD}$.

acute calcium stress on hexose influx was examined immediately after the $20 \mathrm{~h}$ period. ${ }^{3} \mathrm{H}$-deoxy-D-glucose $\left({ }^{3} \mathrm{H}-\mathrm{DG}\right)$ uptake was measured in the absence and in the presence of $5 \mu \mathrm{M}$ cytochalasin $\mathrm{B}$, and facilitative transporter (cytochalasin-sensitive) ${ }^{3} \mathrm{H}-\mathrm{DG}$ flux rate was calculated from the difference of ${ }^{3} \mathrm{H}-\mathrm{DG}$ flux rate without and with cytochalasin B (31). Fig. 2 illustrates that total uptake of $0.1 \mu \mathrm{M}{ }^{3} \mathrm{H}-\mathrm{DG}$ increased in LLC-PK1 cells exposed to A23187 from a control rate of $29.8 \pm 1.5$ pmoles $/ \mathrm{mg}$ protein/min to $45.3 \pm 1.9(P<0.0001)$. The majority of the increased transport activity was due to cytochalasin B-sensitive ${ }^{3} \mathrm{H}-\mathrm{DG}$ flux, which was $13.7 \pm 1.5 \mathrm{pmoles} / \mathrm{mg}$ protein $/ \mathrm{min}$ in

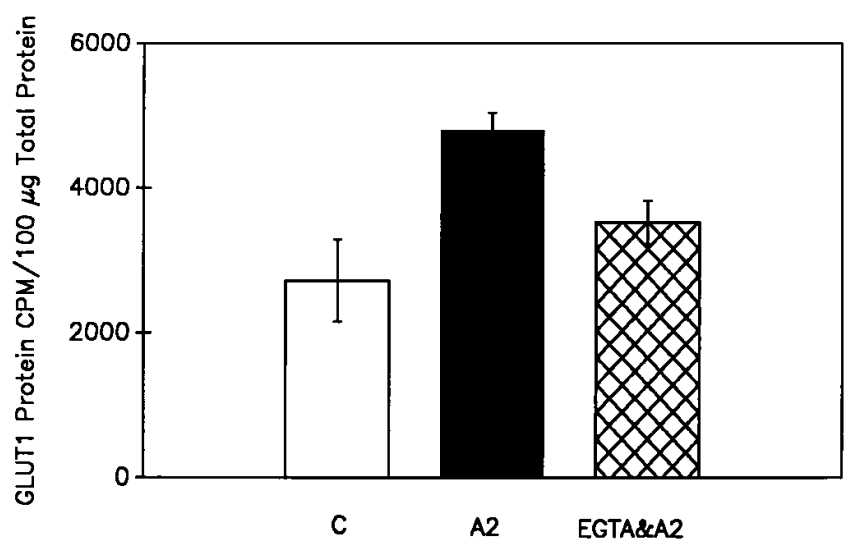

Figure 9. Plot of GLUT1 protein levels assessed by $\beta$ radioactivity scanning. The findings in the three experiments illustrated in Fig. 5 were confirmed by $\beta$ radioactivity scanning of the membranes. Treatment with A23187 stimulated a significant increase in GLUT1 protein $(A 2)$, compared to control cells $(C)$, and prior chelation with EGTA blunted the response to A23187 (EGTA\&A2).
A. $-66 \mathrm{kD}$

GLUT 1

B.
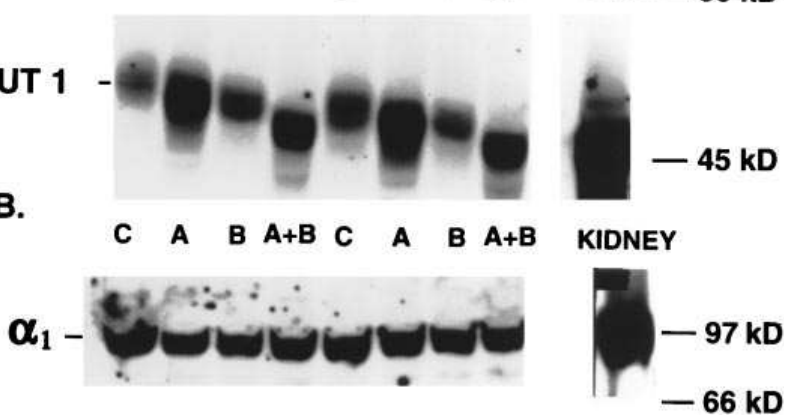

Figure 10. Western blot analysis of GLUT1 and the $\alpha_{1}$ subunit of $\mathrm{Na}^{+} / \mathrm{K}^{+}$ATPase $\left(\alpha_{1}\right)$ detected in homogenates of LLC-PK1 cells. Four separate groups of cells were included: control $(C)$, exposed to $10 \mu \mathrm{M}$ A23187 (A2), preloaded with $20 \mu \mathrm{M}$ BAPTA-AM $(B)$, and preloaded with $20 \mu \mathrm{M}$ BAPTA-AM followed by $10 \mathrm{mM}$ A23187 $(B \& A 2)$. GLUT1 protein levels increased after exposure to $10 \mu \mathrm{M}$ A23187 and chelation with BAPTA attenuated the effect of the ionophore. In contrast, steady state levels of the $\alpha_{1}$ subunit of $\mathrm{Na}^{+} / \mathrm{K}^{+} \mathrm{AT}$ Pase were not changed by the experimental conditions. The transport proteins were detected after size-fractionation of protein $(100 \mu \mathrm{g})$ by immunoblotting with GLUT1 or $\alpha_{1}$ subunit of $\mathrm{Na}^{+} / \mathrm{K}^{+}$ATPase antibodies. Numbers indicate apparent molecular weight in $\mathrm{kD}$.

control cells and $23.2 \pm 1.9$ in cells exposed to the ionophore $(P=0.002)$. We surmise that a substantial proportion of the response to A23187 is mediated through GLUT1, the only glucose transporter sensitive to cytochalasin B in LLC-PK1 cells (21).

The higher hexose uptake in LLC-PK1 cells exposed to A23187 was accompanied by corresponding increases in glucose consumption and lactate production, Fig. 3. Confluent LLC-PK1 cells were cultured for 4, 12, and $24 \mathrm{~h}$ (Methods) in the presence of $2 \mathrm{mM}$ glucose and $10 \mu \mathrm{M}$ phlorizin with either $0.1 \%$ DMSO (controls) or $10 \mu \mathrm{M}$ A23187. The inhibitor phlorizin was added to block glucose influx through the apical $\mathrm{Na}^{+} /$ glucose cotransporter system expressed in LLC-PK1 cells (21, 26). After $4 \mathrm{~h}$, media glucose and lactate concentrations were

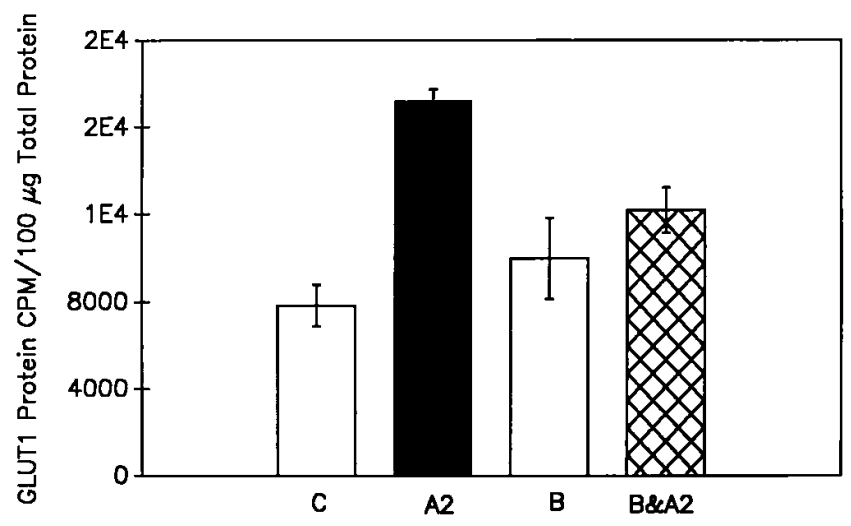

Figure 11. Plot of GLUT1 protein levels assessed by $\beta$ radioactivity scanning. Findings in the three experiments shown in Fig. 7 were confirmed by $\beta$ radioactivity scanning of the membranes. There was a significant increase in GLUT1 protein above control $(C)$ treatment with A23187 (A2). BAPTA loading did not change GLUT1 levels significantly $(B)$, whereas prior chelation with BAPTA blunted the response to $\mathrm{A} 23187(B \& A 2)$. 
$1.38 \pm 0.06$ and $0.11 \pm 0.04 \mathrm{mM}$ in control cells and $1.34 \pm 0.06$ and $0.40 \pm 0.06$ in cells exposed to A23187. These two sets of values were not statistically different between the two groups $(P>0.05)$. However, after $12 \mathrm{~h}$, medium glucose and lactate levels in controls, $1.35 \pm 0.05$ and $1.03 \pm 0.07$, were significantly different than in cells exposed to A23187, 1.03 \pm 0.03 and $2.03 \pm 0.07$ ( $P<0.05$ for both groups $)$. After $24 \mathrm{~h}$ the differences were even greater; glucose and lactate levels in controls were $0.92 \pm 0.01$ and $1.93 \pm 0.04$ and in cells exposed to A23187 were $0.30 \pm 0.02$ and $3.42 \pm 0.03$ ( $P<0.05$ for both groups $)$.

Changes in cytosolic free calcium and GLUT1 mRNA. The next series of experiments were designed to define the cellular mechanism activated by A23187, which caused higher hexose uptake and glucose consumption in LLC-PK1 cells. Initially, the association between cytosolic free calcium $\left(\mathrm{Ca}^{2+}{ }_{\mathrm{i}}\right)$ and GLUT1 mRNA levels in LLC-PK1 cells exposed to A23187 was confirmed (Fig. 4). $\mathrm{Ca}^{2+}{ }_{\mathrm{i}}$ was measured in LLC-PK1 cells loaded with the fluorescent $\mathrm{Ca}^{2+}$ indicator fura-2 (30) before and after addition of $0.1 \%$ DMSO or $1-10 \mu \mathrm{M}$ A23187. GLUT1 mRNA was measured on dot blots. After exposure to $0.1 \%$ DMSO or A23187 for $4 \mathrm{~h}$, GLUT1 mRNA and 28S rRNA were measured and expressed as the fractional ratio GLUT1 mRNA/28S rRNA $\times 100$. The levels of $\mathrm{Ca}^{2+}{ }_{\mathrm{i}}$ and GLUT1 mRNA levels were not altered by addition of $0.1 \%$ DMSO to the culture media. However, incremental exposure to $\mathrm{A} 23187$, from 1 to $10 \mu \mathrm{M}$, increased $\mathrm{Ca}^{2+}{ }_{\mathrm{i}}$ and GLUT1 mRNA levels proportionally. $\mathrm{Ca}^{2+}{ }_{\mathrm{i}}$ increased (in $\mathrm{nM}$ ) by $\Delta=$ $+45, \Delta=+287$, and $\Delta=+432(n=2)$ after adding $1,2.5$, and $10 \mu \mathrm{M}$ A23187. GLUT1mRNA/28S rRNA $\times 100$ increased from $20.1 \pm 1.4$ in control cells exposed to DMSO to 55.1 $\pm 3.8(n=3, P<0.05)$ in cells exposed to $10 \mu \mathrm{M}$ A23187.

The relationship of $\mathrm{Ca}^{2+}{ }_{i}$ and GLUT1 gene expression was also examined in cells exposed to A23187 while internal or external $\mathrm{Ca}^{2+}$ was chelated with BAPTA-AM and EGTA, respectively (Fig. 5). $\mathrm{Ca}^{2+}{ }_{\mathrm{i}}$ levels were monitored in three groups of cells before and after addition of $10 \mu \mathrm{M}$ A23187-4 bromo to the assay buffer. The first group of cells were not treated before A23187, and $\mathrm{Ca}^{2+}{ }_{\mathrm{i}}$ increased from a basal level of $247 \pm 24$ $\mathrm{nM}$ to $663 \pm 63(\Delta=+416 \pm 64, n=7)$. The second group of cells were first exposed to $2 \mathrm{mM}$ EGTA, which reduced basal $\mathrm{Ca}^{2+}{ }_{\mathrm{i}}$ to $166 \pm 15 \mathrm{nM}$ (significantly lower than the first group; $P=0.015)$ and after $\mathrm{A} 23187 \mathrm{Ca}^{2+}{ }_{\mathrm{i}}$ only increased to $374 \pm 27$ $(\Delta=+208 \pm 38, n=7$, significantly lower than the first group; $P=0.016)$. In the third group, cells were first loaded with 20 $\mu \mathrm{M}$ BAPTA-AM, and basal $\mathrm{Ca}^{2+}{ }_{\mathrm{i}}, 185 \pm 10$, was not significantly lower than control $(P=0.07)$. However, after A23187, $\mathrm{Ca}^{2+}$ i only increased to $290 \pm 9(\Delta=+105 \pm 14, n=5$, a value significantly lower than the first group, $P=0.002)$. These experiments demonstrated that external (EGTA) and internal (BAPTA-AM) chelation of $\mathrm{Ca}^{2+}$ blunted the acute rise of $\mathrm{Ca}^{2+}{ }_{\mathrm{i}}$ evoked by A23187.

GLUT1 $m R N A$ and cognate protein levels. The effect of $\mathrm{Ca}^{2+}$ stress induced with $10 \mu \mathrm{M}$ A23187 on GLUT1 mRNA levels from LLC-PK1 cells is shown in Fig. 6. LLC-PK1 cells were exposed to vehicle (0.1\% DMSO), $10 \mu \mathrm{M}$ A23187, or 2 mM EGTA immediately followed by $10 \mu \mathrm{M}$ A23187 for $4 \mathrm{~h}$. The cells were washed three times with PBS and then cultured in fresh media without additions for another $20 \mathrm{~h}$. At this point, total RNA was isolated, size-fractionated by agarose gel electrophoresis, transferred to nylon membranes, and hybridized under high stringency conditions with ${ }^{32} \mathrm{P}$-labeled GLUT1 and $28 \mathrm{~S}$ rRNA cDNA probes. After exposure to A23187 for

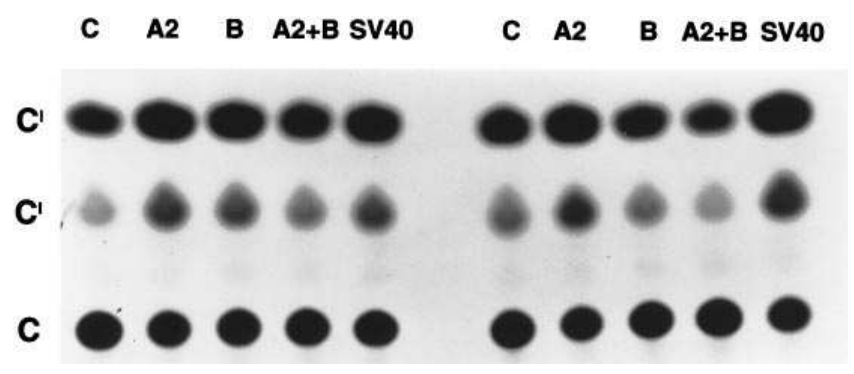

Figure 12. Chloramphenicol acetyltransferase (CAT) activity in lysates from LLC-PK1 cells transiently cotransfected with pGPCAT $_{333}$ and pC110 constructs (see Fig. 1). CAT enzymatic activity was higher in LLC-PK1 cells exposed to A23187 (A2) than in control cells $(C)$. BAPTA chelation did not change basal CAT activity $(B)$, but, attenuated the effect of $\mathrm{A} 23187(B \& A 2)$. The $\mathrm{C}$ label in the bottom of the vertical legend represents authentic chloramphenicol. The middle and upper $\mathrm{C}^{\prime}$ represent the converted monoacetylated and diacetylated forms of chloramphenicol, respectively. The data include two independent representative experiments.

$4 \mathrm{~h}$, GLUT1 mRNA levels increased and chelation of extracellular $\mathrm{Ca}^{2+}$ with EGTA blunted the effect of A23187. GLUT1 mRNA levels were normalized to the content of 28S rRNA measured on the same membranes (Fig. 7) and expressed as GLUT1 mRNA/28S rRNA $\times 100$. In control cells, the fractional ratio was $4.2 \pm 0.4$ and increased to $15.3 \pm 1.3$ in cells treated with A23187 $(P<0.05)$. However, the stimulatory effect of A23187 was significantly reduced to $10.8 \pm 0.2(P<0.05$ vs. A23187 alone) when external $\mathrm{Ca}^{2+}$ was chelated with EGTA.

The levels of GLUT1 protein were measured in cells from the same three groups (Control, A23187, and EGTA + A23187). Total cellular proteins were size-fractionated by polyacrylamide gel electrophoresis, immobilized on nitrocellulose filters, and reacted with specific transporter antibodies followed by ${ }^{125}$ I-protein A. GLUT1 protein migrated as a broad band (43-55 kD) as previously described (20) (Fig. 8). From these representative immunoblots it appeared that exposure to

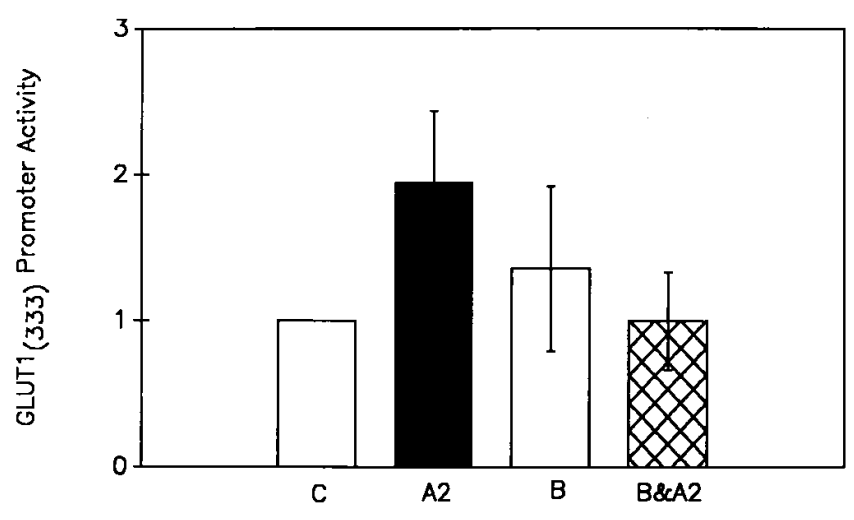

Figure 13. Plot of CAT activity assessed by $\beta$ radioactivity scanning. Findings in three independent experiments, including the two illustrated in Fig. 9, were confirmed by $\beta$ radioactivity scanning of the membranes. CAT activity increased significantly after A23187 (A2) compared to control $(C)$. BAPTA loading did not change CAT activity significantly $(B)$, whereas prior chelation with BAPTA blunted the response to $\mathrm{A} 23187(B \& A 2)$. 


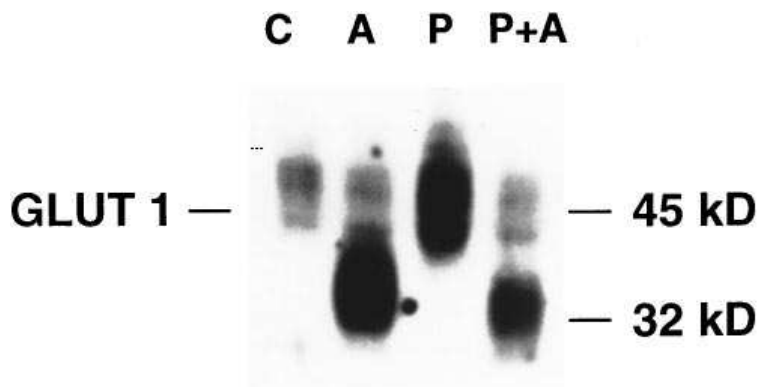

Figure 14. Western blot analysis of GLUT1 detected in homogenates of LLC-PK1 cells. Four separate groups of cells were included: control cells exposed to $0.1 \%$ DMSO $(C)$, exposed to $10 \mu \mathrm{M} \mathrm{A} 23187(A)$, exposed to phloretin $0.2 \mathrm{mM}$ immediately before addition of $0.1 \%$ DMSO $(P)$, and exposed to phloretin $0.2 \mathrm{mM}$ immediately before addition of $10 \mu \mathrm{M}$ A23187 $(P+A)$. GLUT1 protein level increased after exposure to $10 \mu \mathrm{M}$ A23187 and its apparent molecular weight was reduced. Phloretin by itself also caused an increase in GLUT1 protein level, but when added before A23187, phloretin attenuated the increase in GLUT1 protein level (see Table I).

A23187 was associated with an increase of GLUT1 protein levels and that preexposure to EGTA blunted the response. These findings were confirmed by $\beta$ radioactivity scanning of the blots in all subsequent experiments (Fig. 9). Interestingly, the increase in GLUT1 protein level was associated with a corresponding decrease in the apparent molecular weight of GLUT1 (compare GLUT1 sizes between groups in Figs. 8 and $10)$. On the other hand, exposure to $A 23187$, with or without EGTA, did not affect the levels or the apparent size of the $\alpha_{1}$ subunit of $\mathrm{Na}^{+} / \mathrm{K}^{+}$ATPase $\left(\alpha_{1}\right)$ in LLC-PK1 cells (Fig. 8).

The influence of cell $\mathrm{Ca}^{2+}$ on the upregulation of GLUT1 gene expression was verified with a different experimental protocol, using the intracellular chelator BAPTA-AM (see above) (Fig. 10). LLC-PK1 cells were first exposed to vehicle ( $0.1 \%$ DMSO) or $20 \mu \mathrm{M}$ BAPTA-AM for $1 \mathrm{~h}$, washed three times, incubated with or without $10 \mu \mathrm{M}$ A23187 for $4 \mathrm{~h}$, washed, and then allowed to recover in fresh media for 20 additional hours. As noted above, after exposure to A23187, GLUT1 protein levels increased with an apparent reduction in its molecular weight. A summary of the results obtained by detection of the $\beta$ radioactivity on the immunoblots is shown in Fig. 11. LLC-PK1 cells exposed to A23187 increased their GLUT1 protein levels 2.2 \pm 0.1 -fold over control cells $(P<$ $0.001)$. BAPTA alone had a minimal effect, $1.27 \pm 0.23$-fold $(P=0.4)$, but when added before A23187, BAPTA reduced the effect of A23187 to only 1.55 \pm 0.14 -fold from control $(P=$ 0.017 vs. A23187 alone). Cell DNA measured at the end of the experiment was $102 \pm 5 \mu \mathrm{g} / 78.5 \mathrm{~cm}^{2}$ culture dish in controls and remained relatively constant in the other three groups. DNA level in cells treated with A23187 was 97 \pm 7 , in cells loaded with BAPTA it was $96 \pm 11$, and in cells loaded with BAPTA and then exposed to A23187 it was $96 \pm 12$ ( $P>0.5$ for all).

GLUT1 gene transcription. Since exposure to A23187 increased both GLUT1 mRNA and protein, we tested the idea that in cells under $\mathrm{Ca}^{2+}$ stress the GLUT1 gene was transcriptionally activated. First, we developed a new plasmid reporter construct, pUCAT. We then subcloned into pUCAT a 333-bp promoter fragment located at the $3^{\prime}$ end of the promoter located in the $5^{\prime}$ flanking region of the GLUT1 gene.
This segment is flanked at the $5^{\prime}$ end $3^{\prime}$ ends by SmaI and XhoI restriction sites, respectively (44). This novel construct termed pGPCAT $_{333}$ (Fig. 1) was used to report the transcription of the GLUT1 gene in transient transfection experiments of LLC-PK1 cells. To test the effectiveness of pGPCAT $\mathrm{T}_{333}$, LLC-PK1 cells were first cotransfected with 10, 15, and $20 \mu \mathrm{g}$ of pGPCAT $_{333}$ DNA and with $1.5 \mu \mathrm{g}$ of pC110 plasmid DNA, containing the $\beta$ galactosidase gene driven by the simian virus 40 early promoter (SV40 promoter, 45,46$)$. The addition of the GLUT1 promoter fragment strongly induced the CAT gene with a percent conversion of native to acetylated ${ }^{14} \mathrm{C}$ chloramphenicol of $62 \pm 8,83 \pm 2$, and $93 \pm 1 \%$ per dish, whereas LLC-PK1 cells cotransfected with pC110 and pUCAT without the GLUT1 promoter insert, while expressing $\beta$ galactosidase, demonstrated complete absence of CAT activity, and served as negative controls in all transfection experiments (not shown). The positive controls were cells cotransfected with the constructs pRSVCAT $(46)$ and pC110 $(45,46)$ and expressed CAT activity of $98 \pm 1 \%$.

Basal CAT activity in LLC-PK1 cells cotransfected with pGPCAT $_{333}, 7.5 \mu \mathrm{g}$ and pC110, $1.5 \mu \mathrm{g} / 78.5 \mathrm{~cm}^{2}$ dish, was $34 \pm 8 \%$ conversion of ${ }^{14} \mathrm{C}$-chloramphenicol normalized to $\beta$ galactosidase activity. The controls were incubated with vehicle $(0.1 \%$ DMSO) for $4 \mathrm{~h}$, washed, and then incubated in fresh media for 20 more hours. The second group of cells were incubated with A23187 for $4 \mathrm{~h}$ and then allowed to recover for $20 \mathrm{~h}$ in fresh media. In these cells CAT activity increased to $60 \pm 1 \%$ $(P=0.03)$. A third group of cells was preloaded with BAPTAAM, $20 \mu \mathrm{M}$, and then treated like the first group. BAPTA alone did not affect CAT activity: $39 \pm 6 \%(P=0.5)$. In the fourth group of cells, BAPTA preloading reduced to $31 \pm 8 \%$ ( $P=0.8$ vs. controls) the stimulation of CAT activity induced by subsequent exposure to A23187 for $4 \mathrm{~h}$, as described in the second group (Figs. 12 and 13). The negative controls, represented by cells cotransfected with pUCAT without the GLUT1 promoter, did not express CAT activity.

GLUT1 transport function and cytotoxicity. Since activation of GLUT1 gene by A23187 was understood to be part of the stress response that increased hexose transport activity and glycolysis, we tested if the greater activity of GLUT1 was protective to LLC-PK1 cells under $\mathrm{Ca}^{2+}$ stress. LLC-PK1 cells were cultured in the presence of $5 \mathrm{mM}$ glucose, $10 \mu \mathrm{M}$ phlorizin, with or without $0.1 \mathrm{mM}$ phloretin, added immediately before a 4-h period of exposure to either $0.1 \%$ DMSO (vehicle) or $10 \mu \mathrm{M}$ A23187 in $0.1 \%$ DMSO. The cells were washed and cultured for an additional period of $16 \mathrm{~h}$ in fresh medium containing either DMSO (vehicle) and phlorizin with or without phloretin. The results of these experiments are summarized in Table I and Fig. 14. Cell injury caused by A23187 stimulated glycolysis, as indicated by increased glucose consumption and lactate production. The ionophore was cytotoxic, as demonstrated by the fourfold rise in LDH release, although cell viability, represented by DNA content, was comparable to control cells only exposed to DMSO. The addition of A23187 to the media also increased GLUT1 protein levels and as previously illustrated (Figs. 8 and 10), the apparent size of the GLUT1 protein was reduced to $\sim 35 \mathrm{kD}$ (Fig. 14). Phloretin, an inhibitor of facilitative glucose transporters, reduced cellular glucose consumption and lactate production and also potentiated the cytotoxicity and lethality of A23187, as indicated by greater cellular LDH release and lower DNA levels, respectively. It is noteworthy that phloretin alone evoked a remarkable 


\begin{tabular}{lcccc}
\hline \multicolumn{1}{c}{ Parameter } & Control & A23187 & Phloretin & $\begin{array}{c}\text { Phloretin and } \\
\text { A23187 }\end{array}$ \\
\hline Glucose consumption $(\mathrm{mM})$ & $1.63 \pm 0.3$ & $2.13 \pm 0.04^{*}$ & $0.63 \pm 0.02^{*}$ & $0.64 \pm 0.02^{\ddagger}$ \\
Lactate production $(\mathrm{mM})$ & $3.14 \pm 0.13$ & $3.87 \pm 0.06^{*}$ & $1.35 \pm 0.02^{*}$ & $1.65 \pm 0.03^{\ddagger}$ \\
GLUT1 protein fold increase & 1.0 & $3.09 \pm 0.32^{*}$ & $2.13 \pm 0.14^{*}$ & $1.68 \pm 0.11^{\ddagger}$ \\
$\quad$ from control & & & \\
\% LDH released & $0.32 \pm 0.04$ & $4.15 \pm 0.11^{*}$ & none & $18.73 \pm 1.62^{\ddagger}$ \\
Cell DNA ( $\mu$ g/DISH) & $27.1 \pm 1.6$ & $24.9 \pm 0.7$ & $25.1 \pm 0.6$ & $15.6 \pm 0.4^{\ddagger}$ \\
\end{tabular}

A23187 $=10 \mu \mathrm{M}$ A23187, Phloretin $=0.1 \mathrm{mM}$ phloretin. The experimental values are significantly different from either *control or A23187 ${ }^{\ddagger}$ alone, $P<0.05$ (ANOVA).

increase in the level of GLUT1 protein, which was of similar molecular weight to the mature GLUT1 protein expressed in control cells. Thus, $\mathrm{Ca}^{2+}$ cytotoxicity increased GLUT1 expression in LLC-PK1 cells, and inhibition of GLUT1 activity was accompanied by greater cytotoxicity and significant mortality.

\section{Discussion}

LLC-PK1 cells injured by a $\mathrm{Ca}^{2+}$ ionophore (47) increased facilitative deoxyglucose uptake, glucose consumption, and lactate production. The results show that a great proportion of stimulated hexose transport activity was mediated through the glucose transporter GLUT1, because GLUT1 is the only facilitative glucose transporter expressed in LLC-PK1 cells (21) and also because the changes in transport occurred in conjunction with increases in the levels of GLUT1 transcription, mRNA, and cognate protein. A relatively small increase in cytochalasin-insensitive hexose uptake was also observed, which may represent hexose flux through apical $\mathrm{Na}^{+} /$glucose cotransporters (26).

The stimulation of the GLUT1 gene by A23187 was in part secondary to mobilized $\mathrm{Ca}^{2+}{ }_{i}$, in that increases of $\mathrm{Ca}^{2+}{ }_{\mathrm{i}}$ and GLUT1 mRNA levels were proportional, and more significantly, chelation of extracellular and intracellular $\mathrm{Ca}^{2+}$ attenuated the stimulation of GLUT1 gene transcription and the increase of GLUT1 mRNA and protein levels. Exposure to A23187 not only increased the level of GLUT1 protein, but it also reduced the apparent size of GLUT1 protein on SDS gels. These two findings may represent an increase in the half-life $\left(t_{1 / 2}\right)$ of new GLUT1 protein that was less glycosylated than mature GLUT1 protein (35), as shown for cells under $\mathrm{Ca}^{2+}$ (48) or starvation (49) stress. We presume that $\mathrm{Ca}^{2+}$ chelation did not entirely block the stimulation of GLUT1 because $\mathrm{Ca}^{2+}{ }_{\mathrm{i}}$ mobilization by A23187 was not entirely abrogated by either of the two chelators. On the other hand, $\mathrm{Ca}^{2+}$-independent activation of GLUT1 may also play a prominent role in the response to injury. Indeed, it is fitting to consider that renal stress responses to hypoxic or chemical renal injuries may not be dependent on changes of $\mathrm{Ca}^{2+}$, which are not always detected in damaged renal tubules (50).

We used a transient transfection model of LLC-PK1 cells to investigate the role of GLUT1 gene transcription on the activation by $\mathrm{A} 23187$. The transfected vector, $\mathrm{pGPCAT}_{333}$, expressed abundant CAT basal activity, which is consistent with constitutive expression of GLUT1 (44), and A23187 further increased CAT activity. This effect was mediated to some extent by increases of cell $\mathrm{Ca}^{2+}$, since chelation with BAPTA-AM blunted the effect of A23187. The signal activator of GLUT1 transcription stimulated by $\mathrm{Ca}^{2+}{ }_{\mathrm{i}}$ is unknown. It is possible that $\mathrm{Ca}^{2+} /$ calmodulin-dependent functions regulated GLUT1 gene expression as shown for other genes (51). However, other controlling mechanisms, such as stabilization of GLUT1 mRNA or protein, cannot be ruled out as regulators of GLUT1 gene expression.

The protective value of stimulated GLUT1 to stressed LLC-PK1 cells was demonstrated by inhibiting with phloretin the transport activity of GLUT1 before exposure to A23187. The interruption of the response with phloretin, an inhibitor of facilitative glucose transporters (20), prevented the increase in glucose consumption, aborted the concomitant stimulation of cell glycolysis, and enhanced cytotoxicity and cell mortality. A comparable adverse outcome may occur during aminoglycoside nephrotoxicity, where injury may be aggravated by failure to translate the activation of GLUT1 into a higher number of transporters (23).

The response of GLUT1 gene to $\mathrm{Ca}^{2+}$ stress is not limited to kidney cells (22) and may represent a more generalized reaction to injury. We suggest that this reaction involves the recruitment of GLUT1 and other genes critical for cell survival, such as the regulation of DNA synthesis $(5,52)$ and protein processing $(9,14)$. We surmise that GLUT1 activation leads to greater glycolytic flux, which protects cultured cells subjected to $\mathrm{Ca}^{2+}$ stress (51). The protective mechanism is most likely derived from ATP production (1-4), although generation of intracellular acidosis (53) may afford additional protection (54). We realize that glycolysis is not a prominent energy source for normal renal tubular cells in vivo $(1,2)$, and it is conceivable that metabolic responses of damaged renal tubules may be different than those of LLCPK1 cells. However, in view of the activation of GLUT1 in injured tubules (23), and the rapid switch to glycolysis observed in hypoxic proximal tubules $(1,2)$, one may envision that in vivo GLUT1 and glycolysis play prominent roles in the recovery of injured tubules. Accordingly, we conclude that in renal cell injury, increases of $\mathrm{Ca}^{2+}{ }_{\text {i }}$ participate in the flow of information that culminates in greater glucose transport. This stress response enhances cell recovery after injury, and its disruption could lead to greater cell damage and even cell death.

\section{Acknowledgments}

We thank Becky McClain for technical assistance and Dr. Alain Baron for the use of the glucose/lactate analyzer. We also thank Dr. 
David B. Rhoads (Harvard University) for his gift of pig GLUT 1 cDNA, Dr. Morris J. Birnbaum (Harvard University) for his gift of the GLUT1 promoter and Dr. David Crabb (Indiana University) for his gift of 28S rRNA cDNA.

This work was supported with funds from National Institutes of Health (grants \#DK-39655 and \#DK-43640), the Department of Veterans Affairs, the Juvenile Diabetes Foundation, and the American Diabetes Association to J.H. Dominguez.

\section{References}

1. Dickman, K.G., and L.J. Mandel. 1989. Glycolytic and oxidative metabolism in primary renal proximal tubule cultures. Am. J. Physiol. 257(26):C333C340.

2. Dickman, K.G., and L.J. Mandel. 1990. Differential effects of respiratory inhibitors on glycolysis in proximal tubules. Am. J. Physiol. 258(27):F1608F1615.

3. Bashan, N., E. Burdett, H.S. Hundal, and A. Klip. 1992. Regulation of glucose transport and GLUT1 glucose transporter expression by $\mathrm{O}_{2}$ in muscle cells in culture. Am. J. Physiol. 262(31):C682-C690.

4. Bashan, N., E. Burdett, A. Guma, R. Sargeant, L. Tumiati, Z. Liu, and A. Klip. 1993. Mechanisms of adaptation of glucose transporters to changes in the oxidative chain of muscle and fat cells. Am. J. Physiol. 264(33):C430-C440.

5. Bartlett, J.D., J.D. Luethy, S.G. Carlson, S.J. Sollott, and N.J. Holbrook. 1992. Calcium ionophore A23187 induces expression of the growth arrest and DNA damage inducible CCAAT/enhancer-binding protein (C/EBP)-related gene, gadd153. J. Biol. Chem. 267:20465-20470.

6. Chen, Q., K. Yu, N.J. Holbrook, and J.L. Stevens. 1992. Activation of the growth arrest and DNA damage-inducible gene gadd153 by nephrotoxic cysteine conjugates and dithiothreitol. J. Biol. Chem. 267:8207-8212.

7. Chen, Q., K. Yu, and J.L. Stevens. 1992. Regulation of the cellular stress response by reactive electrophiles. J. Biol. Chem. 267:24322-24327.

8. Emami, A., J.H. Schwartz, and S.C. Borkan. 1991. Transient ischemia or heat stress induces a cytoprotectant protein in rat kidney. Am. J. Physiol. 260: F479-F485.

9. Li, W.W., S. Alexandre, X. Cao, and A.S. Lee. 1993. Transactivation of the grp78 promoter by $\mathrm{Ca}^{2+}$ depletion. A comparative analysis with A23187 and the endoplasmic reticulum $\mathrm{Ca}^{2+}$-ATPase. J. Biol. Chem. 268:12003-12009.

10. Liu, E.S., and A.S. Lee. 1991. Common sets of nuclear factors binding to the conserved promoter sequence motif of two coordinately regulated ER protein genes, GRP78 and GRP94. Nucleic Acids Res. 19:5425-5431.

11. Price, B.D., and K.S. Calderwood. 1992. Gadd45 and Gadd153 messenger RNA levels are increased during hypoxia and after exposure of cells to agents which elevate the levels of the glucose-regulated proteins. Cancer Res. 52:3814-3817.

12. Shetty, M., N. Ismail-Beigi, J.N. Loeb, and F. Ismail-Beigi. 1993. Induction of GLUT1 mRNA in response to inhibition of oxidative phosphorylation. Am. J. Physiol. 265:(34):C1224-C1229.

13. Wooden, S.K., L.J. Li, D. Navarro, I. Qadri, L. Pereira, A.S. Lee, and S. Amy. 1991. Transactivation of the grp 78 promoter by malfolded proteins, glycosylation block, and calcium ionophore is mediated through a proximal region containing a CCAAT motif which interacts with CTF/NF-I. Mol. Cell. Biol. 11: 5612-5623.

14. Yamamoto, N., A. Maki, J.D. Swann, I.K. Berezesky, and B.F. Trump. 1993. Induction of immediate early and stress genes in rat proximal tubule epithelium after injury: The significance of cytosolic ionized calcium. Renal Fail. 15:163-171.

15. Zeller, W.P., M. Sweet, M. Goto, M.E. Gottschalk, R.M. Hurley, J.P. Filkins, and C. Hofmann. 1991. Altered glucose transporter mRNA abundance in a rat model of endotoxic shock. Biochem. Biophys. Res. Commun. 176:535540 .

16. Smith, M.W., P.C. Phelps, and B.F. Trump. 1992. Injury-induced changes in cytosolic $\mathrm{Ca}^{2+}$ in individual rabbit proximal tubule cells. Am. J. Physiol. 262(31):F647-F655.

17. Ueda, N., and Shah, S.V. 1992. Role of intracellular calcium in hydrogen peroxide-induced renal tubular cell injury. Am. J. Physiol. 263:F214-F221.

18. Trump, B.F., and I.K. Berezesky. 1992. The role of cytosolic $\mathrm{Ca}^{2+}$ in cell injury, necrosis, and apoptosis. Curr. Opin. Cell Biol. 4:227-232.

19. Ron, D. 1994. Inducible growth arrest: new mechanistic insights. Proc. Natl. Acad. Sci. USA. 91:1985-1986.

20. Dominguez, J.H., K. Camp, L. Maianu, and W.T. Garvey. 1992. The glucose transporters of rat proximal tubule: differential expression and subcellular distribution. Am. J. Physiol. 262(31):F807-F812.

21. Ohta, T., K.J. Isselbacher, and D.B. Rhoads. 1990. Regulation of glucose transporters in LLCPK1 cells: effects of D-glucose and monosaccharides. Mol. Cell Biol. 10:6491-6499.

22. Wertheimer, E., S. Sasson, E. Cerasi, and Y. Ben-Neriah. 1991. The ubiquitous glucose transporter GLUT-1 belongs to the glucose-regulated protein family of stress-inducible proteins. Proc. Natl. Acad. Sci. USA. 88:2525-
2529 .

23. Dominguez, J.H., C.C. Hale, and M. Qulali. 1996. Studies of renal injury I. Gentamicin toxicity and the expression of genes encoding basolateral transporters of rat renal proximal tubules. Am. J. Physiol. 270(39):F245-F253.

24. Greene, E.L., and M.S. Paller. 1994. Calcium and free radicals in hypoxia/reoxygenation injury of renal epithelial cells. Am. J. Physiol. 266(35) F13-F20.

25. Hull, R.N., W.R. Cherry, and G.W. Weaver. 1976. Origin and characteristics of a pig kidney cell strain, LLC-PK1. In Vitro (Rockville). 12:670-677.

26. Mullin, J.M., J. Weibel, L. Diamond, and A. Kleinzeller. 1980. Sugar transport in the LLC-PK1 renal epithelial cell line: similarity to mammalian kidney and the influence of cell density. J. Cell Physiol. 104:375-389.

27. Yeh, C.K., I.S Ambudkar, and E. Kousvelari. 1992. Differential expression of early response genes, c-jun, c-fos, and jun B, in A5 cells. Am. J. Physiol. 263(26):G934-G938.

28. Bradford, M. 1976. A rapid and sensitive method for the quantitation of microgram quantities of protein utilizing the principle protein-dye bonding. Anal. Biochem. 102:248-254.

29. Labarca, C., and K. Paigen. 1980. A simple, rapid, and sensitive DNA assay procedure. Anal. Biochem. 102:344-352.

30. Dominguez, J.H., J.G.N. Garcia, J.K. Rothrock, D. English, and C Mann. 1991. Fluoride mobilizes intracellular calcium and promotes $\mathrm{Ca}^{2+}$ influx in rat proximal tubules. Am. J. Physiol. 261(30):F318-F327.

31. Cheung, P.T., and M.R. Hammerman. 1988. $\mathrm{Na}^{+}$-independent D-glucose transport in rabbit renal basolateral membranes. Am. J. Physiol. 254(23): F711-F718.

32. Korzeniewski, C., and D. Callewaert. 1983. An enzyme release assay for natural cytotoxicity. J. Immunol. Methods. 64:313-320.

33. Laemmli, U.K. 1970. Cleavage of structural proteins during the assembly of the head of bacteriophage $\mathrm{T}_{4}$. Nature (Lond.). 227:680-685.

34. Towbin, H., T. Staehelin, and J. Gordon. 1979. Electrophoretic transfer of proteins from polyacrylamide gels to nitrocellulose sheets: procedure and some applications. Proc. Natl. Acad. Sci. USA. 76:4350-4354.

35. Haspel, C.H., M.G. Rosenfeld, and O.M. Rosen. 1979. Characterization of antisera to a synthetic carboxyl-terminal peptide of the glucose transporter protein. J. Biol. Chem. 263:398-403.

36. Chomczynski, P., and N. Sacchi. 1987. Single-step method of RNA isolation by acid guanidinium thiocynate-phenol-chloroform extraction. Anal. Biochem. 162:156-159.

37. Southern, E.M. 1975. Detection of specific sequences among DNA fragments separated by gel electrophoresis. J. Mol. Biol. 98:503-517.

38. Thomas, P.S. 1980. Hybridization of denatured RNA and small DNA fragments transferred to nitrocellulose. Proc. Natl. Acad. Sci. USA. 77:52015205 .

39. Birnbaum, M.J., H.C. Haspel, and O.M. Rosen. 1986. Cloning and characterization of a cDNA encoding the rat brain glucose transporter protein. Proc. Natl. Acad. Sci. USA. 83:5784-5788.

40. Chan, Y.L., R. Gutell, H.F. Noller, and I.G. Wool. 1984. The nucleotide sequence of a rat $18 \mathrm{~S}$ ribosomal ribonucleic acid gene and a proposal for the secondary structure of $18 \mathrm{~S}$ ribosomal ribonucleic acid. J. Biol. Chem. 259:224 230.

41. Feinberg, A., and B. Vogelstein. 1984. A technique for radiolabelling DNA restriction endonuclease fragments to high specific activity. Anal. Biochem. 137:266-273.

42. Sambrook, J., E.F. Fritsch, and T. Maniatis. 1989. Molecular Cloning. A Laboratory Manual. Volume I. Cold Spring Harbor Laboratory Press, Cold Spring Harbor, NY

43. Gorman, C.M., L.F. Moffat, and B.H. Howard. 1982. Recombinant genomes which express chloramphenicol acetyltransferase in mammalian cells Mol. Cell. Biol. 2:1044-1051.

44. Williams, S.A., and M.J. Birnbaum. 1988. The rat facilitated glucose transporter gene. Transformation and serum-stimulated transcription initiate from identical sites. J. Biol. Chem. 263:19513-19518.

45. Kingston, R.E. 1994. Introduction of DNA into mammalian cells. In Current Protocols in Molecular Biology, Volume I. F.M. Ausubel, R. Brent R.E. Kingston, D.D. Moore, J.G. Seidman, J.A. Smith, and K. Struhl, editors Wieley Interscience. Boston, MA. 9.1.1-9.7.21.

46. Gorman, C.M., G.T. Merlino, M.C. Willingham, I. Pastan, and B.H Howard. 1982. The Rous sarcoma virus long terminal repeat is a strong promoter when introduced into a variety of eukaryotic cells by DNA-mediated transfection. Proc. Natl. Acad. Sci. USA. 79:6777-6781.

47. Jiang, T., R.L. Grant, and D. Acosta. 1993. A digitized fluorescence imaging study of intracellular free calcium, mitochondrial integrity and cytotoxicity in rat renal cells exposed to ionomycin, a calcium ionophore. Toxicology. 85: $41-65$.

48. Di Jeso, B., D. Liguoro, P. Ferranti, M. Marinaccio, R. Acquavira, S. Formisano, and E. Consiglio. 1992. Modulation of the carbohydrate moiety of thyroglobulin by thyrotropin and calcium in Fisher rat thyroid line-5 cells. $J$. Biol. Chem. 267:1938-1944.

49. McMahon, R.J., and S.C. Frost. 1995. Nutrient control of GLUT1 processing and turnover in 3T3-L1 adypocytes. J. Biol. Chem. 270:12094-12099.

50. Jacobs, W.R., M. Sgambati, G. Gomez, P. Vilaro, M. Higdon, P.D. Bell, 
and L.J. Mandel. 1991. Role of cytosolic Ca in renal tubule damage induced by anoxia. Am. J. Physiol. 260(29):C545-C554.

51. Enslen, H., and T.R. Sodering. 1994. Roles of calmodulin-dependent protein kinases and phosphatase in calcium-dependent transcription of immediate early genes. J. Biol. Chem. 269:20872-20877.

52. Luethy, J.D., J. Fargnoli, J.S. Park, A.J. Fornace, and N.J. Holbrook. 1990. Isolation and characterization of the hamster gadd153 gene. J. Biol. Chem. 265:16521-16526.
53. Martinez, G.M., R. Martinez-Zaguilan, and R.J. Gillies. 1994. Effect of glucose on $\mathrm{pH}_{\text {in }}$ and $\left[\mathrm{Ca}^{2+}\right]_{\text {in }}$ in NIH-3T3 cells transfected with the yeast p-type $\mathrm{H}^{+}$ATPase. J. Cell. Physiol. 161:129-141.

54. Weinberg, J.M., J.A. Davis, N.F. Roeser, and M.A. Venkatachalam. 1991. Role of increased cytosolic free calcium in the pathogenesis of rabbit proximal tubule cell injury and protection by glycine or acidosis. J. Clin. Invest. $87: 581-590$ 